\title{
Observed and projected climate shifts 1901-2100 depicted by world maps of the Köppen-Geiger climate classification
}

\author{
FrANZ RUBEL $^{1 *}$ and MARKUS KOTTEK ${ }^{2}$ \\ ${ }^{1}$ University of Veterinary Medicine Vienna, Austria \\ ${ }^{2}$ Carinthian Institute for Climate Protection, Klagenfurt, Austria \\ (Manuscript received September 7, 2009; in revised form December 15, 2009; accepted February 2, 2010)
}

\begin{abstract}
In a previous paper we presented an update of the highly referenced climate classification map, that of Wladimir Köppen, which was published for the first time in 1900 and updated in its latest version by Rudolf Geiger in 1961. This updated world map of Köppen-Geiger climate classification was based on temperature and precipitation observations for the period 1951-2000. Here, we present a series of digital world maps for the extended period 1901-2100 to depict global trends in observed climate and projected climate change scenarios. World maps for the observational period 1901-2002 are based on recent data sets from the Climatic Research Unit (CRU) of the University of East Anglia and the Global Precipitation Climatology Centre (GPCC) at the German Weather Service. World maps for the period 2003-2100 are based on ensemble projections of global climate models provided by the Tyndall Centre for Climate Change Research. The main results comprise an estimation of the shifts of climate zones within the 21 st century by considering different IPCC scenarios. The largest shifts between the main classes of equatorial climate (A), arid climate (B), warm temperate climate (C), snow climate (D) and polar climate (E) on global land areas are estimated as 2.6-3.4 \% (E to D), 2.2-4.7\% (D to C), 1.3-2.0 (C to B) and 2.1-3.2\% (C to A).
\end{abstract}

\begin{abstract}
Zusammenfassung
In einer vorangegangenen Arbeit präsentierten wir eine Aktualisierung der am häufigsten verwendeten Karte der Klimaklassifikation, jener von Wladimir Köppen, die erstmals 1900 vorgestellt und in der letzten Auflage von Rudolf Geiger 1961 aktualisiert wurde. Diese aktualisierte Weltkarte der Köppen-Geiger Klimaklassifizierung basierte auf Beobachtungen der Temperatur und des Niederschlags der Periode 19512000. Hier stellen wir eine Serie von digitalen Weltkarten für die erweiterte Periode 1901-2100 vor, um globale Trends des beobachteten Klimas sowie Trends in vorhergesagten Klimaszenarien zu beschreiben. Die Weltkarten des Beobachtunszeitraums 1901-2002 basieren auf aktuellen Datensätzen der Climatic Research Unit (CRU) der Universität von East Anglia und des Weltzentrums für Niederschlagsklimatologie (WZN) am Deutschen Wetterdienst. Weltkarten für den Zeitraum 2003-2100 basieren auf Ensemble-Projektionen von globalen Klimamodellen, die vom Tyndall Centre for Climate Change Research bereitgestellt werden. Die wichtigsten Ergebnisse beinhalten eine Abschätzung der Verschiebungen der Klimazonen im 21. Jhd. unter Berücksichtigung verschiedener IPCC Szenarien. Die größten Verschiebungen zwischen den Hauptklassen äquatoriales Klima (A), arides Klima (B), warm gemäßigtes Klima (C), Schneeklima (D) und polares Klima (E) der globalen Landflächen werden mit 2,6-3,4\% (E zu D), 2,2-4,7 \% (D zu C), 1,3-2,0 (C zu B) und 2,1-3,2 \% (C zu A) abgeschätzt.
\end{abstract}

\section{Introduction}

Recently, a world map of Köppen-Geiger climate classification based on temperature and precipitation observations for the period 1951-2000 was published by KOTTEK et al. (2006). Both the printed map and the underlying digital data have been provided to the scientific community free of charge via the website http://koeppengeiger.vu-wien.ac.at/. Already a short-time after the release of the digital world map of Köppen-Geiger climate classification it was used in various studies, mostly to relate research results to regional climates. It became popular mainly in the fields of zoology, parasitology and public health (DIAZ et al., 2007; LLOYD et al., 2007).

\footnotetext{
*Corresponding author: Franz Rubel, Biometeorology and Mathematical Epidemiology Group, Institute for Veterinary Public Health, University of Veterinary Medicine Vienna, 1210 Vienna, Austria, e-mail: franz.rubel@vetmeduni.ac.at
}

Direct use of the digital data set was made for example to review micrometeorological flux measurements in Asia (Mizoguchi et al., 2009), to investigate the effect of particulate air pollution on mortality in the USA (ZANOBETTI and SCHWARTZ, 2009) and to identify climate type represented by fossil flora (UTESCHER et al., 2009). KотTEK and Rubel (2007) applied the digital database to regionalize spatial auto-correlation functions applied to objectively analyze global daily precipitation fields by block kriging. Even the first geographical textbooks (RAW, 2008; KUTTLER, 2009) desisted from depicting the historical hand-drawn map, as usual in geography, and made use of the new digital world map of Köppen-Geiger climate classification.

Here, additional world maps of Köppen-Geiger climate classification depicting the shift of climate zones in the past, present and future are presented. Because of the lack of global datasets, the pioneers of the effective 


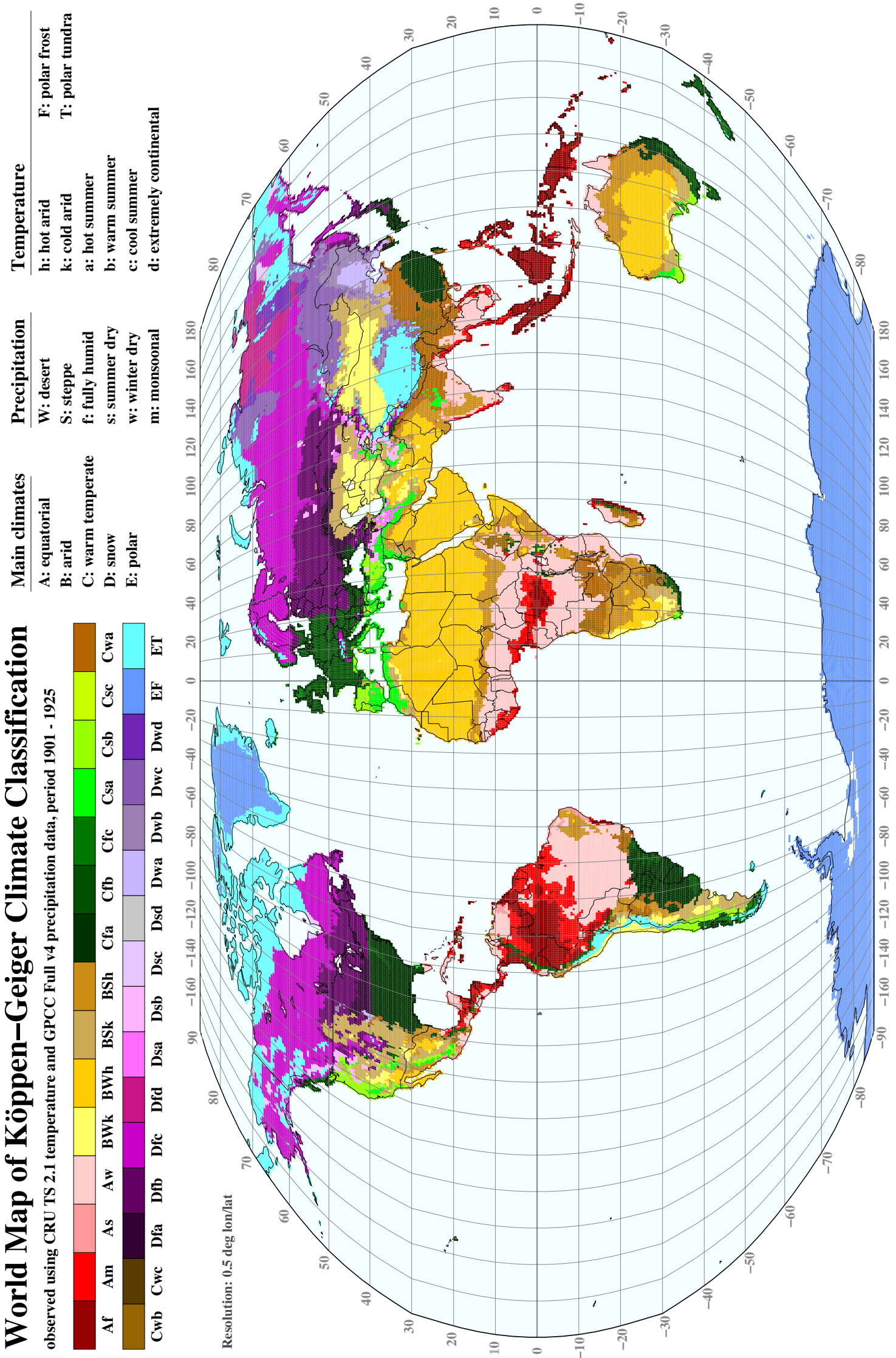

Figure 1: World Map of Köppen-Geiger climate classification calculated from observed temperature and precipitation data for the period 1901-1925 on a regular 0.5 degree latitude/longitude grid. 

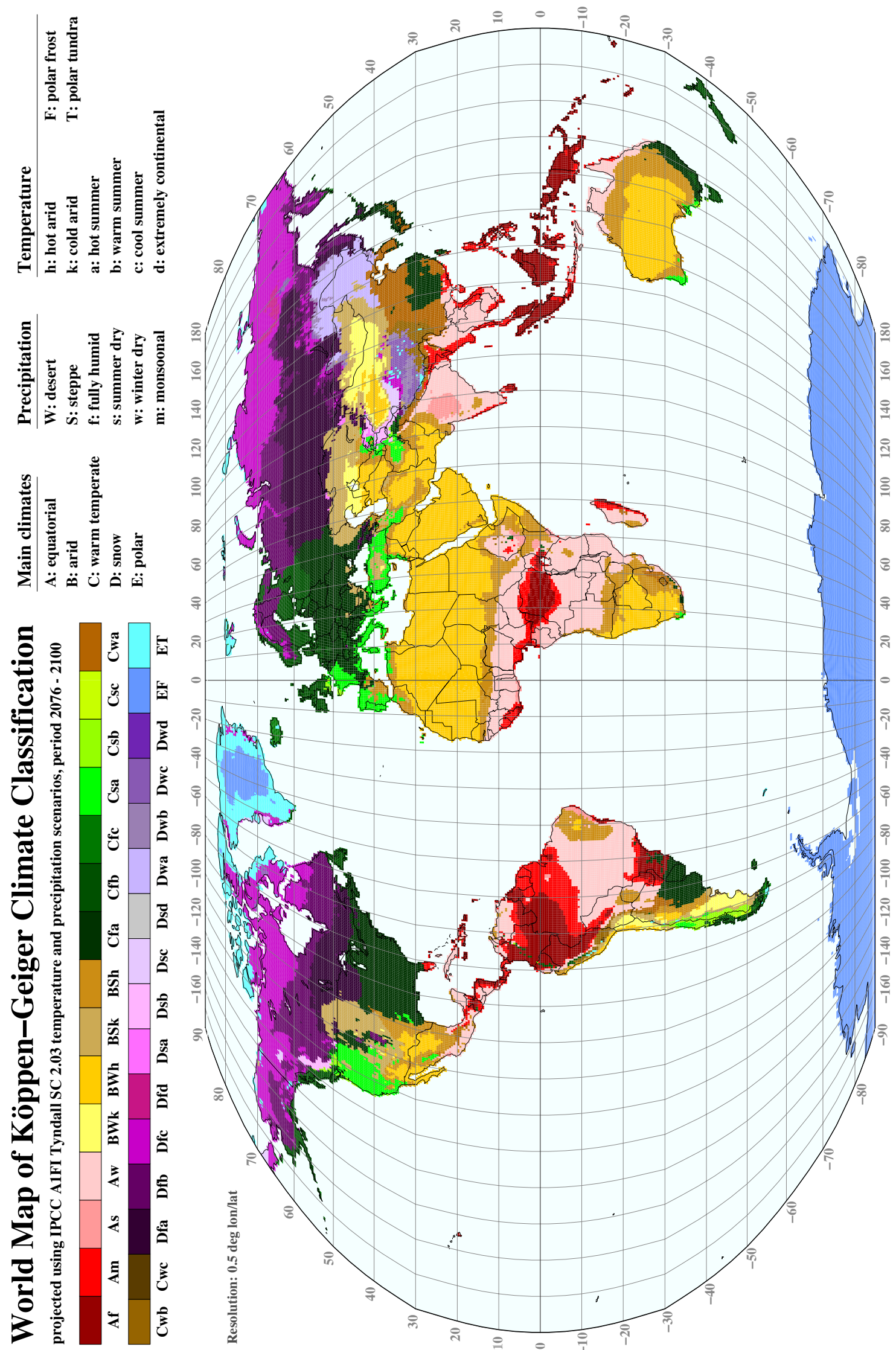

Figure 2: World Map of Köppen-Geiger climate classification projected with Tyndall temperature and precipitation data for the period 2076-2100, A1FI emission scenario, on a regular 0.5 degree latitude/longitude grid. 
climate classification, the German scientists Wladimir Köppen (1846-1940) and Rudolf Geiger (1894-1981), were not able to compile such time series of climate classification. They had to collect all available observations to prepare one single world map (GEIGER, 1961). Observed global temperature and precipitation datasets collected during recent years offer the possibility to compile a 100-years time series of global maps of KöppenGeiger climate classification. Associated temporal and spatial trends were investigated in previously published papers for example by FRAEDRICH et al. (2001) and focused on Europe - by GERSTENGARBE and WERNER (2009). In this paper, the observational period was extended by global climate model (GCM) projections to cover the 200-year period 1901-2100.

One of the first applications calculating KöppenGeiger climate classifications from temperature and precipitation projections was presented by MANABE and HOLLOWAY (1975). They used the climate classification to simply verify the output of a GCM. Further, climate classifications provide an excellent method for model intercomparison, as demonstrated by DE CASTRO et al. (2007) to investigate climatic change in Europe using an ensemble of nine regional climate models. Here, ensemble projections from $5 \mathrm{GCMs}$ applied to 4 emission scenarios defined by the Intergovernmental Panel on Climate Change (IPCC) and described in the Special Report on Emission Scenarios (SRES) were used. Unlike previous studies, climate models are not investigated concerning their differences but they are used to provide ensemble means of global temperature and precipitation distributions to estimate Köppen-Geiger maps of possible future worlds.

Therewith fundamental climate trends become visible. These trends comprise for example the decreased permafrost in high-latitudes of the Northern hemisphere (WANG and OVERLAND, 2004) or the increased aridity in the Mediterranean area in Southern Europe (GAO and GIORGI, 2008). However, the spatial resolution of the world maps of climate classifications is not yet high enough to depict small-scale features such as the disappearing "alpine tundra" Köppen climatic type in the western United States as described by DIAZ and EISCHEID (2007).

\section{Data and Method}

Two global datasets of climate observations were selected to calculate world maps of Köppen-Geiger climate classes. Both are available on a regular 0.5 degree latitude/longitude grid with monthly temporal resolution. The first dataset is provided by the Climatic Research Unit (CRU) of the University of East Anglia (MitCHELL and JONES, 2005) and delivers grids of monthly climate observations from meteorological stations comprising nine climate variables from which only temperature is used in this study. The temperature fields have been analysed from time-series observations, which are checked for inhomogeneities in the station-records by an automated method. This dataset, referred to as CRU TS 2.1, covers the global land areas excluding Antarctica. The second dataset, provided by the Global Precipitation Climatology Centre (GPCC) located at the German Weather Service, is the so-called GPCC's Full Data Reanalysis Version 4 for 1901-2007 (FUCHS, 2008). This recently updated gridded precipitation dataset covers the global land areas excluding Greenland and Antarctica. Most of the meteorological and hydrological services of the world as well as the hosts of the global precipitation station databases - CRU, the Global Historical Climatology Network (GHCN) at the National Climatic Data Center (NCDC), Food and Agriculture Organization (FAO) of the United Nations - and the hosts of some regional precipitation datasets contributed to the GPCC precipitation data base. All observations in this station data base are subject to a multistage quality control to minimise the risk of generating temporal inhomogeneities in the gridded data due to varying station densities. Both, CRU TS 2.1 and GPCC's full data reanalysis version 4 are publicly available and cover the period 1901 to 2002 selected in this study to calculate Köppen-Geiger maps based on observations.

Global temperature and precipitation projections for the period 2003-2100 were taken from the Tyndall Centre for Climate Change Research dataset, TYN SC 2.03 (Mitchell et al., 2004). It comprises a total of 20 GCM runs, combining 4 possible future worlds of emission scenarios described by SRES (ARNELL et al., 2004) with 5 state-of-the-art climate models. The emission scenarios were developed in the mid 1990s and are based on 4 different storylines to describe consistently the relationships between the forces driving emissions and their evolution and to add context for the scenario quantification. Each storyline represents different world futures: A world with quick economic growth and a quick launch of new and efficient technologies (A1), a very heterogenic world with focus on family values and local traditions (A2), a world without materialism and launch of clean technologies (B1) and a world with focus on local solutions for economic and ecological sustainability (B2). The variables in each model include population growth, economic development, energy use, efficiency of energy use, and mix of energy technologies, respectively. The TYN SC 2.03 dataset considers the scenarios A1FI (fossil fuel intensive), A2, B1 and B2. Five general circulation models were used to simulate climatic changes: The Hadley Centre Coupled Model Version 3 (HadCM3), the National Center for Atmospheric Research-Parallel Climate Model (NCARPCM), the Second Generation Coupled Global Climate Model (CGCM2), the Industrial Research Organization - Climate Model Version 2 (CSIRO2) and the European Centre Model Hamburg Version 4 (ECHam4). Since 
the GCMs had a substantially coarser spatial resolution than 0.5 degree, MitCHELL et al. (2004) interpolated the GCM-patterns to the higher resolution by applying an Delaunay triangulation and by relating them to the observed temperatures 1961-1990. To estimate future Köppen-Geiger climate classifications, ensemble-means from the $5 \mathrm{GCM}$ runs for temperature and precipitation have been calculated for each of the 4 emission scenarios.

The calculation scheme for the Köppen-Geiger classes applied here was briefly described by KOTTEK et al. (2006). It comprises a total of 31 climate classes described by a code of three letters. The first letter describes the main classes, namely equatorial climates (A), arid climates (B), warm temperate climates (C), snow climates (D) and polar climates (E). The second letter accounts for precipitation and the third letter for temperature classes (see also the legends of Fig. 1 and Fig. 2).

In the past Wladimir Köppen and Rudolf Geiger regarded the climate as constant and used all of the sparse climate information available at their time to compile a single map. ${ }^{1}$ To consider climate change, the question about the shortest period to be selected for a representative world map of climate classification arises. More precisely, one has to define the lower limit of the length of an averaging interval to get a representative climate map. FRAEDRICH et al. (2001) solved this by statistically investigating the climate shift during the observational period 1901-1995 for 15 Köppen-Geiger climate classes. Their result was an optimal averaging interval of above 15 years and they stated further that longer time intervals do not lead to a significant change in the trend. According to this considerations, the Köppen-Geiger climate classification maps presented here were calculated from temperature and precipitation data averaged over periods of 25 years.

\section{Results}

Applying a 25 year running average to the observed and projected monthly temperature and precipitation data, a total of 176 Köppen-Geiger climate classification maps was compiled for each of the 4 emission scenarios covering the period 1901-2100. They are archived as computer animations and available via the internet (http://koeppen-geiger.vu-wien.ac.at/). Two of these world maps, one for the observational period 1901-1925 and one for the projection period 2076-2100, are depicted in Fig. 1 and Fig. 2. The map representing the IPCC A1FI emission scenario was selected for Fig. 2 to show the scenario with maximum climate shift. For a further printed map we refer to KOTTEK et al. (2006), who published a map representative for the current climate period 1951-2000.

\footnotetext{
${ }^{1}$ The first map of climate classification was published by KÖPPEN (1900), the latest version by GEIGER (1961).
}
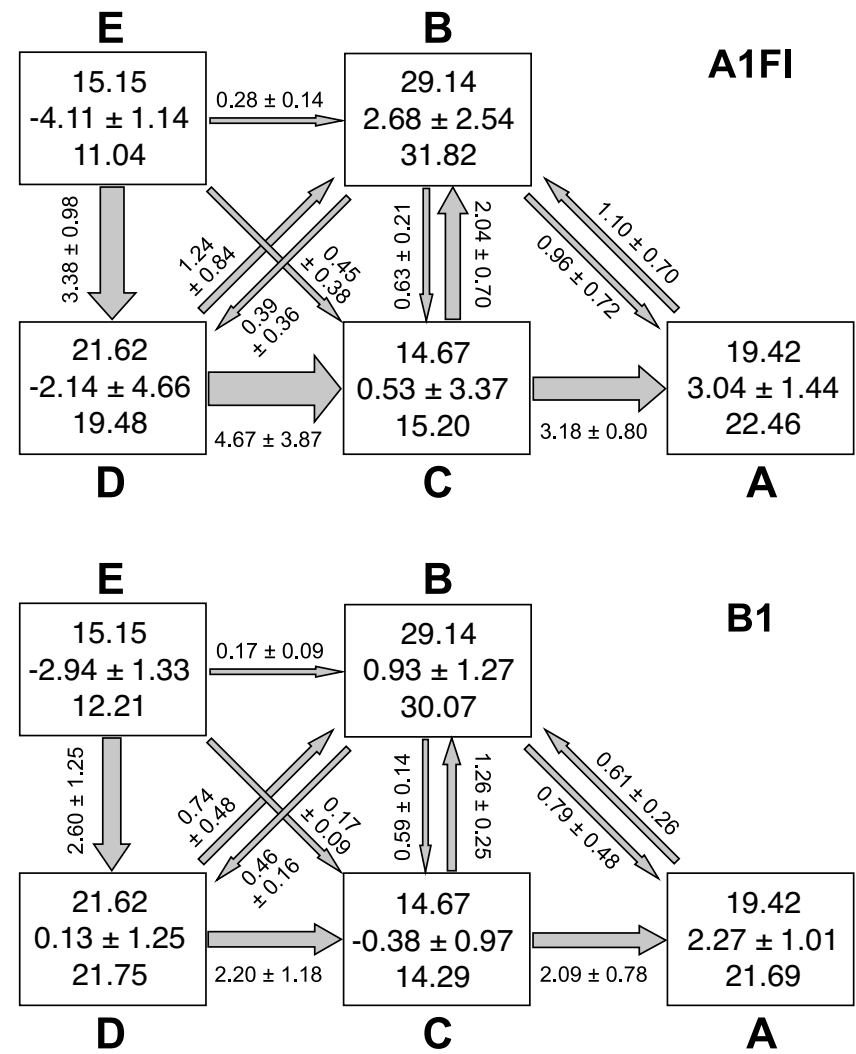

Figure 3: Shifts between main Köppen-Geiger climate classes of the periods 1976-2000 vs. 2076-2100 for IPCC A1FI (top panel) and B1 (bottom panel) emission scenario. Mean values and range of 5 GCM projections are given in percentage of the global land area covered by climate data. Note that $1 \%$ corresponds to an area of $1.43 \cdot 10^{6} \mathrm{~km}^{2}$.

Most visible climate change may be found in the Northern hemispheric $30-80^{\circ}$ belt, where B, C, D and E climates successively shifts to the north. Regarding the whole globe, the shift of climate zones within the $21^{\text {st }}$ century, exactly for the 100 years period 1976 2000 vs. 2076-2100, is depicted in Fig. 3. Again the extreme scenarios have been selected to demonstrate climate change. The A1FI scenario shows the largest shifts, the B1 scenario the smallest shifts between the main Köppen-Geiger climate classes. Values for A2 and B2 scenarios (not shown) are within this range.

In the observational period 1976-2000 a total of 29.14 $\%$ of the global land area is covered by climates of type B, followed by $21.62 \%$ D climates, $19.42 \%$ A climates, $15.15 \%$ E climates and $14.67 \% \mathrm{C}$ climates, respectively. Assuming an A1FI emission scenario for the period 2076-2100 (Fig. 3, top panel), the ensemble mean of the $5 \mathrm{GCM}$ projections results in an increased coverage of $22.46 \%$ of A climates $(+3.04 \%), 31.82 \%$ of B climates $(+2.68 \%), 15.20 \%$ of C climates $(+0.53 \%)$ as well as a decreased coverage of $11.04 \%$ of E climates $(-4.11 \%)$ and $19.48 \%$ of D climates $(-2.14 \%)$. Significantly smaller shifts of climate zones were projected for the B1 emission scenario (Fig. 3, lower panel). Ad- 
ditionally, in contrast to an increased coverage projected for the A1FI scenario, a decreased coverage of $\mathrm{C}$ climates was projected for the B1 scenarios.

The shifts between the main climate classes (grey arrows in Fig. 3) are maximal around the D climates. For example, concerning the A1FI emission scenario, the maximum shift was projected from $\mathrm{D}$ to $\mathrm{C}$ climates $(4.67 \pm 3.87 \%)$ and for the B1 emission scenario from $\mathrm{E}$ to $\mathrm{D}(2.60 \pm 1.25 \%)$. Not only the climate shifts, but also the uncertainties between the $5 \mathrm{GCM}$ projections are generally smaller for the B1 scenario. The spatial shift between the main climates and the sub-climates is assessed by visually comparing Fig. 1 and Fig. 2. As for the main climates, the change is maximal for D subclimates Dfb, Dfc and Dfd. Further climate shifts are visible for example in the tropics, where areas covered by Af and Am climates increase. The latter visualizes the widening of the tropical belt as recently explained by SEIDEL et al. (2007).

\section{Conclusion}

A series of new world maps of Köppen-Geiger climate classification depicting spatial and temporal trends is presented here and as supplemental material on the internet at http://koeppen-geiger.vu-wien.ac.at/. It comprises the first projected maps of global climate classification calculated on a 0.5 degree grid. Other projected maps of global climate classification were calculated onto the much coarser grid resolution of the involved GCMs (KALVOVÁ et al., 2003). On a regional scale, however, for several studies high resolution maps were compiled. RODERFELD et al. (2008), for example, described the potential impact of climate change on ecosystems of the Barents Sea region by Köppen climate classifications evolved from 0.5 degree resolution Regional Climate Model (REMO) simulations. Their Köppen climate classification employed to northern Europe, represented by REMO and the underlying B2 scenario, corresponds quite well with our maps. A further regional study was presented by BAKER et al. (2010) to investigate climate change in China. Instead of regional climate model projections, the authors applied the GCM data from HadCM3 and PCM, which were downscaled using the additional information of observed climate data analyzed on a grid of $4 \mathrm{~km}^{2}$. As in our study, the GCM data are taken from the TYN SC 2.0 dataset, calculated for A1FI and B1 SRES scenarios.

The regional studies discussed above demonstrate possible applications of our global climate maps. Therefore, our paper provides only a brief description of climate trends depicted by series of Köppen-Geiger maps. Users are invited to draw conclusions for their regions of interest and apply the digital datasets for their own studies. Particular advantage is expected for studies which relate the abundance of plants, animals or pathogens not exclusively to current climates but also to projections of past and future climates. Many of these studies may also benefit from the printed world maps avoiding the more expensive application of the digital dataset.

\section{Acknowledgments}

The Tyndall Centre for Climatic Change Research at the University of East Anglia, UK, and the Global Precipitation Climatology Centre (GPCC) in Offenbach, Germany, provided the data. We thank Peter FINGER (GPCC) for assisting the data transfer as well as Tobias FUCHS and Bruno RUDOLF for discussing the application.

\section{References}

Arnell, N.W., M.J.L. Livermore, S. Kovats, P. E. LeVy, R. Nicholls, M. L. PARry, S. R. GAFFin, 2004: Climate and socio-economic scenarios for globalscale climate change impacts assessments: Characterising the SRES storylines. - Glob. Environ. Change 14, 3-20.

BAKer, B., H. Diaz, W. Hargrove, F. HofFMAn, 2010: Use of the Köppen-Trewartha climate classification to evaluate climatic refugia in statistically derived ecoregions for the People's Republic of China. - Climate Change 98, 113131.

de Castro, M., C. Gallardo, K. Jylha, H. TuOmenVIRTA, 2007: The use of a climate-type classification for assessing climate change effects in Europe from an ensemble of nine regional climate models. - Climate Change 81, 329-341.

DiAZ, H.F., J.K. EISCHEID, 2007: Disappearing 'alpine tundra' Köppen climatic type in the western United States. - Geophys. Res. Lett. 34, L18707; doi:10.1029/2007GL031253.

Diaz, P., A. Paz-Silva, R. SAnchez-Andrade, J. L. SuArez, J. Pedreira, M. Arias, P. Diez-Banos, P. Morrondo, 2007: Assessment of climatic and orographic conditions on the infection by Calicophoron daubneyi and Dicrocoelium dendriticum in grazing beef cattle (NW Spain). - Vet. Parasitol. 149, 285-289.

Fraedrich, K., F.-W. Gerstengarbe, P.C. Werner, 2001: Climate shift during the last century. - Climate Change 50, 405-417.

FuCHS, T., 2008: GPCC's Full Data Reanalysis Version 4 for 1901-2007. Personal Communication, data available at ftp://ftpanon.dwd.de/pub/data/gpcc/html/fulldata_download.html.

GAO, X., F. GIORGI, 2008: Increased aridity in the mediterranean region under greenhouse gas forcing estimated from high resolution simulations with a regional climate model. - Glob. Planet. Change 62, 195-209.

GEIGER, R., 1961: Überarbeitete Neuausgabe von Geiger, R.: Köppen-Geiger / Klima der Erde. (Wandkarte 1:16 Mill.) - Klett-Perthes, Gotha.

Gerstengarbe, F.-W., P. C. Werner, 2009: A short update on Koeppen climate shifts in Europe between 1901 and 2003. - Clim. Change 92, 99-107.

Kalvová, J., T. HalenkA, K. Bezpalcová, I. NEMEŠOVÁ, 2003: Köppen climate types in observed and simulated climates. - Stud. Geophys. Geod. 47, 185-202. 
KÖPPEN, W., 1900: Versuch einer Klassifikation der Klimate, vorzugsweise nach ihren Beziehungen zur Pflanzenwelt. - Geographische Zeitschrift 6, 593-611, 657-679.

Kottek, M., F. RuBeL, 2007: Global daily precipitation fields from bias-corrected rain gauge and satellite observations. Part I: Design and development. - Meteorol. Z. 16, 525-539.

Kottek, M., J. Grieser, C. Beck, B. Rudolf, F. RUBEL, 2006: World map of the Köppen-Geiger climate classification updated. - Meteorol. Z. 15, 259-263.

Kuttler, W., 2009: Grundriss Allgemeine Geographie: Klimatologie - Schöning, Paderborn, 260 S.

Lloyd, S.J., R.S. Kovats, B.G. Armstrong, 2007: Global diarrhoea morbidity, weather and climate. - Climate Res. 34, 119-127.

MAnABE, S., J. L. Holloway, 1975: The seasonal variation of the hydrologic cycle as simulated by a global model of the atmosphere. - J. Geophys. Res. 80, 1617-1649.

Mitchell, T. D., P. D. Jones, 2005: An improved method of constructing a database of monthly climate observations and associated high-resolution grids. - Int. J. Climatol. 25, 693-712.

Mitchell, T. D., T. R. Carter, P. D. Jones, M. Hulme, M. NEW, 2004: A comprehensive set of high-resolution grids of monthly climate for Europe and the globe: the observed records (1901-2000) and 16 scenarios (2001-2100).
Tyndall Centre of Climate Change Research, Working Paper 55.

Mizoguchi, Y., A. Miyata, Y. Ohtani, R. HiRata, S. YUTA, 2009: A review of tower flux observation sites in Asia. - J. For. Res. 14, 1-9.

RAW, M., 2008: OCR AS Geography - Hodder Education, Deddington, 370 .

Roderfeld, H., E. Blyth, R. Dankers, G. Huse, D. Slagstad, I. Ellingsen, A. Wolf, M. A. Lange, 2008: Potential impact of climate change on ecosystems of the Barents Sea Region. - Climate Change 87, 283-303.

SEIDEL, D.J., Q. FU, W.J. RANDEL, T.J. REICHLER, 2007: Widening of the tropical belt in a changing climate. Nature Geoscience, DOI:10.1038/ngeo.2007.38.

Utescher, T., V. Mosbrugger, D. Ivanov, D. L. DILCHER, 2009: Present-day climatic equivalents of European Cenozoic climates. - Earth Planet. Sci. Lett. 284, 544-552.

WANG, M., J.E. OVERLAND, 2004: Detecting arctic climate change using Köppen climate classification. - Climate Change 67, 43-62.

Zanobetti, A., J. Schwartz, 2009: The effect of fine and coarse particulate air pollution on mortality: A national analysis. - Environ. Health Perspect. 117, 898-903. 